\title{
Przekształcenia Skawińskich Zakładów Koncentratów Spożywczych jako przejaw procesu globalizacji
}

Ważnym nośnikiem procesów globalizacji są wielkie transnarodowe korporacje (TNC) organizujące i przekształcające światową gospodarkę. Skutecznie konkurują one ze światowymi podmiotami takimi jak państwa i organizacje międzynarodowe np. Bank Swiatowy, OECD, Unia Europejska, NAFTA, i in. (Kukliński 2000). Spektakularnym przejawem procesów globalizacji są bezpośrednie inwestycje zagraniczne realizowane głównie przez TNC. Ocena znaczenia tych inwestycji w procesie globalizacji jest różnie oceniana przez przedstawicieli nauki, życia gospodarczego, polityków, organizacji społecznych i politycznych. Nie podlega jednak dyskusji, że bezpośrednie inwestycje zagraniczne stwarzają szanse skrócenia dystansu cywilizacyjnego krajów słabo rozwiniętych, jaki dzieli je do krajów rozwiniętych.

Procesy polaryzacji uwidaczniające się w koncentracji produkcji i dobrobytu w obszarach cechujących się wysokim poziomem rozwoju dokonuje się także w Europie. Proces ten pogłębia dystans w poziomie i tempie rozwoju poszczególnych regionów europejskich. Proces ten zwiększa różnice pomiędzy europejskim centrum wzrostu gospodarczego a jego peryferiami, do których należą państwa Europy Środkowej i Wschodniej. (Makieła 2000).

Coraz wyraźniej zaznaczają się regionalne dysproporcje przestrzennego zagospodarowania, które stawiają nowe wyzwania dla europejskiej polityki rozwoju regionalnego.

Zmniejszanie tempa narastania dysproporcji rozwoju gospodarczego regionów jest procesem trudnym, wymagającym znacznego wysiłku intelektualnego regionalistów i polityków, dużych nakładów finansowych zainteresowanych państw oraz bogatych państw Unii Europejskiej. Znaczący wpływ na tempo procesu rozwoju regionalnego może mieć także globalizacyjna działalność gospodarcza, rozumiana jako wyższy, bardziej złożony i zaawansowany etap umiędzynarodowienia działalności gospodarczej.

Proces globalizacji uruchamia wiele korzystnych mechanizmów ekonomicznych, ale także występują w nim zjawiska negatywne, szczególnie w regionach słabszych o niskim potencjale społeczno-gospodarczym oraz regionach restrukturyzujących gospodarkę i wprowadzających w nich nowe metody zarządzania.

W regionach będących w początkowym okresie przemian (określanym jako adaptacyjny), który obserwujemy obecnie w Polsce, następuje wiele zdarzeń korzystnych dla gospodarki regionu np. zanikanie słabszych podmiotów gospodarczych, ograniczanie przestarzałej produkcji wielu zakładów przemysłowych, zmiana struktury przemysłu poprzez pojawianie się nowych podmiotów, szybki proces prywatyzacji. Obserwuje się również 
narastanie wielu niekorzystnych, dotychczas nieznanych zjawisk, takich jak ograniczanie miejsc pracy, bezrobocie szczególnie w grupie ludzi młodych, rozwarstwienie w poziomie dochodów ludności, pogarszanie się poziomu życia dla dominującej części mieszkańców.

Skutki procesu globalizacji w Europie Środkowej widoczne są w zachodzących zmianach systemu gospodarowania, przechodzenia od gospodarki centralnie sterowanej do gospodarki rynkowej. Najkorzystniejsze warunki w tym procesie mają regiony o relatywnie nowoczesnym zagospodarowaniu infrastrukturą techniczno-ekonomiczną, dużym udziałem przemysłów „high tech", wysoko wykwalifikowaną kadrą pracowników. Są to przeważnie regiony stołeczne, obszary metropolitarne oraz obszary położone wzdłuż europejskich ciągów komunikacyjnych i w sąsiedztwie obszaru UE.

Regiony te już wcześniej wykazywały wyższą dynamikę rozwoju gospodarczego, a dobre zagospodarowanie infrastrukturą techniczno-ekonomiczną przyciąga obecnie na ich obszar inwestycje zagraniczne, tam lokują swoje zakłady produkcyjne i usługowe, powstają filie międzynarodowych banków i innych firm otoczenia biznesu. W procesie tym prawie całkowicie pomijane są obszary charakteryzujące się dominacją tradycyjnego, mało konkurencyjnego przemysłu, większość obszarów rolniczych, a więc regiony o znacznym zapóźnicniu cywilizacyjnym.

W warunkach Polski transformacja gospodarcza spowodowała usunięcie zasadniczych barier politycznych, utrudniających integrowanie się Polski $\mathrm{z}$ gospodarką europejską i światową. Wyrazem tego jest szybki wzrost bezpośrednich inwestycji zagranicznych w Polsce. W 1995 roku zainwestowano nieco ponad 2 mld USD, w 1996 r. - 5,2 mld USD, zaś w 1997 r. - 6,6 mld USD. Łącznie do końca 1997 r. zainwestowano w Polsce ponad 20 mld USD. Zmiany polityczne i gospodarcze Polski były podstawowymi czynnikami pozwalającymi na włączenie naszego kraju w ogólny proces globalizacji.

Ilustracją zarysowanych procesów jest kreowanie filii korporacji transnarodowej z byłych zakładów spożywczych w ramach działalności „Bahlsen-Sweet” spółka z o.o. z siedzibą w Skawinie, należącej do korporacji ponadnarodowej „Bahlsen” GmBH z siedzibą w Hanowerze i „Biogran” spółka z o.o. z siedzibą w Skawinie należącej do holdingu KORD GmBH und K.G. w Hamburgu.

Napływ obcego kapitału do Polski w tym także kapitału firm ponad narodowych „Bahlsen” i „KORD” związany jest z procesem przemian zachodzących w kraju oraz tworzeniu warunków inwestowania dla firm zagranicznych. Przekształcenia struktur przemysłu, szczególnie struktury własnościowej przemysłu było wyraźnym impulsem sprzyjającym procesowi przemian. Przykładem tych zmian jest przekształcenie w 1994 r. Skawińskich Zakładów Koncentratów Spożywczych w jednoosobową spółkę Skarbu Państwa, co umożliwiło jej sprzedaż niemieckiej grupie kapitałowej „Bahlsen”. Grupa ta z siedzibą zarządu w Hanowerze posiada dziesięć fabryk w Europie w tym dwie w Polsce, w Poznaniu (obecna nazwa „Bahlsen - Snacks”) i w Skawinie.

Po trzech latach funkcjonowania zakładów w Skawinie pod nazwą „Bahlsen” S.A., w 1997 r. podzielono ją na dwie części „Bahlsen - Koncentraty Spoźywcze” i „Lajkonik Snacks" S.A. Podział i utworzenie firmy siostry „Lajkonik - Snacks” S.A. powodowane było (wg wersji zarządu firmy) celami reklamy handlowej i konieczności zwiększenia konkurencyjności firmy. Podział firmy na dwa niezależne podmioty mógł wynikać z korzyści ulg podatkowych dla firm zagranicznych. 
Dla realizacji celu przyjęto logo firmy krakowskiego „Lajkonika” na tle średniowiecznej tarczy rycerskiej w kolorze czerwonym lub niebieskim, z napisem lajkonik. Ponadto firma "Lajkonik Snacks" S.A. od 1997r. z powodów rynkowych, przyzwyczajeń klientów, nadal specjalizuje się w produkcji i sprzedaży tylko pieczywa cukierniczego, paluszków i ekstarkt kawy zbożowej „Inka”.

Kolejny etap zmian to sprzedaż wydziału Ekstrakcji Kawy Zbożowej wraz ze znakiem firmowym „Inka”. Sprzedaż części kawowej zakładu, jak wynika z oficjalnej wersji, spowodowana była tym że zakłady Grupy Kapitałowej „Bahlsena” specjalizują się w produkcji pieczywa cukierniczego.

Wydział Ekstrakcji Kawy Zbożowej sprzedano niemieckiemu holdingowi „KORD” GmBH und K.G. z siedzibą w Hamburgu, a firma „Bahlsen” w Skawinie zmieniła nazwę na „Bahlsen - Sweet” spółka z o.o.

Na bazie Skawińskich Zakładów Koncentratów Spożywczych powstała nowa firma: Biogran" spółka z o.o., jako filia korporacji ponad narodowej, holdingu kawowego „KORD” GmBH und K. G. specjalizującego się w produktach typu instant, a szczególnie w produkcji kawy naturalnej instant. Za największy sukces rynkowy holding „KORD” uznaje nie tyle zakup wydziału ekstrakcji kawy zbożowej w Skawinie, co było poszerzeniem produkcji kaw instant o instant kawy zbożowej. Największym sukcesem holding było przejęcie wraz z kupnem zakładu w Skawinie rynków zbytu kawy zbożowej i poszerzenie dla swojej produkcji w Europie Zachodniej, rynków zbytu dla kawy naturalnej o obszar Polski i Europy Środkowo-Wschodniej.

Obecnie holding jest właścicielem sześciu zakładów produkcyjnych, dwóch w Niemczech „Milkcaffe” i „Find Foods International” zajmujących się produkcją cappucino, dwóch zakładów w Belgii „Edel” i w Anglii „CCI” zajmujących się produkcją i konfekcjonowaniem kawy naturalnej instant. Ponadto jeden z zakładów w Niemczech „Creammilk” zajmuje się produkcją mleka instant. (ryc. 1).

Zakład w Skawinie odgrywa ważną rolę w polityce pozyskiwania rynków wschodnich, jako rynków perspektywicznych, a zarazem strategicznych dla holdingu. O randze filii w Skawinie świadczy jej niezależność decyzyjna. Zakład produkcji kawy instant typu "Inka” w Skawinie, ze względu na specyfikę rynku wschodniego może podejmować decyzje o znaczeniu strategicznym.

Ponadto holding „KORD” GmBH jest właścicielem plantacji kawy naturalnej położonych w Wenezueli, a zrzeszonych w międzynarodowej grupie „Accafeira”.

W strukturze organizacyjnej holdingu strategiczne znaczenie odgrywa „centrum decyzyjne i rozwoju” z siedzibą w Hamburgu. Organizacyjnie i decyzyjnie podlegają mu wszystkie zakłady holdingu. Decyzje o znaczeniu strategicznym, szczególnie w wyznaczaniu kierunków rozwoju asortymentu produkcji i ekspansji terytorialnej, dużych przedsięwzięć inwestycyjnych, podejmowane są wyłącznie we wspomnianym centrum "KORD” GmBH und K. G. Natomiast obsługą logistyczną i administracyjną zajmuje się Centrum Logistyczno - Administracyjne „DE Caffe” w Hamburgu, podległe organizacyjnie holdingowi. Żadna z firm należących do holdingu, z wyjątkiem firmy „Biogran”, nie posiada uprawnień decyzyjnych. Wynika z tego że firma „Biogran” w Skawinie stanowi jeden z najważniejszych podmiotów holdingu.

Ekspansja dużych firm niemieckich na teren Skawiny wywołuje skutki gospodarcze i społeczne wynikające ze strategii koncernów ponadnarodowych. Zmiany te cechują się 
zróżnicowaną skalą i bezpośrednio wpływają na przemiany struktury aglomeracji krakowskiej, zmieniają strukturę ekonomiczną Skawiny. Zespół przemysłowy Skawiny stanowi więc jedno $\mathrm{z}$ ogniw w globalnej sieci korporacji transnarodowej. Wchłonięty został przez proces globalizacji w wyniku polityki przedsiębiorstw zagranicznych, które traktują aglomerację krakowska jako potencjalny obszar eksportowej penetracji rynku polskiego i „wrota” do rynków Europy Wschodniej. W mniejszym natomiast stopniu jako region, obszar działalności eksportowej.

Przejawem procesu globalizacji dla podmiotów gospodarczych Skawiny i aglomeracji krakowskiej są implikacje o charakterze endogenicznym i egzogenicznym. Zmiany i skutki procesu przekształceń Skawińskich Zakładów Koncentratów Spożywczych dla ludności miasta i gospodarki Skawiny, uwidaczniają się negatywnymi skutkami. należy do nich restrukturyzacja zatrudnienia, która doprowadziła do wzrostu bezrobocia, konieczności poszukiwania pracy daleko poza miejscem zamieszkania a także pogarszania się poziomu życia mieszkańców.

Obserwuje się także wiele korzystnych skutków takich jak: poprawa konkurencyjności podmiotów, wyraźny wzrost aktywności gospodarczej, unowocześnienie produkcji, wdrażanie nowoczesnych technik zarządzania i nowych technologii produkcji.

Wejście obcego kapitału na rynek aglomeracji krakowskiej wywołał wielorakie implikacje $\mathrm{m}$. in. na poziomie nowo powstałych zagranicznych firm, a także implikacje na poziomie lokalnym i regionalnym, krajowym i międzynarodowym.

1. Implikacje na poziomie firmy:

- wdrożenie nowoczesnego systemu zarządzania SAP,

- instalacja nowoczesnego systemu łączności satelitarnej,

- uzyskanie znaku ISO 9001,

- ponad $50 \%$ wzrost mocy produkcyjnych (produkcja ponad 5500 ton kawy zbożowej instant),

- poprawa powtarzalnej jakości produkcji, wdrażanie zaawansowanych technologii produkcji,

- poprawa warunków pracy, poprawa efektywności pracy,

- poprawa wizerunku zewnętrznego zakładu,

- wzrost nakładów inwestycyjnych,

- kształcenie pracowników, głównie kadry kierowniczej.

2. Implikacje na poziomie lokalnym i regionalnym:

- zmniejszenie zatrudnienia o około 800 osób,

- całkowita utylizacja odpadów,

- podatki dla samorządu lokalnego,

- powiązania kooperacyjne z podmiotami na terenie aglomeracji i jej najbliższym otoczeniu,

- umacnianie rozwoju rynku poprzez poszerzanie sektora prywatnego,

3. Implikacje na poziomie krajowym.

- stymulowanie konkurencji na rynku wewnętrznym, m. in. „walka” konkurencyjna z zakładem produkcji kawy zbożowej instant w Poznaniu o dominację na rynku krajowym,

- stabilizowanie cen kawy zbożowej na rynku krajowym,

- stabilizowanie cen skupu zbóż na rynku krajowym, 
- ograniczanie współpracy z kooperantami krajowymi na rzecz zagranicy,

- rozluźnianie powiązań gospodarczych z firmami krajowymi,

- umiędzynarodowienie gospodarki i przebudowa jej międzynarodowych powiązań, np. poprzez ścisłe związki kooperacyjne z podmiotami z obszaru Unii Europejskiej, głównie z firmami kawowymi,

- poszerzanie rynków zbytu o kraje Europy Wschodniej

Z punktu widzenia dłuższej perspektywy czasu zmiany te prowadzą do trwałej poprawy funkcjonowania firm przemysłowych a także gospodarki lokalnej i regionalnej.

\section{Literatura}

Dabrowski W., 1998. Zarzqdzanie promocja bezpośrednich inwestycji zagranicznych. [w:] Bezpośrednie inwestycje zagraniczne w Polsce. Praca zbiorowa pod red. Z. Olesińskiego. PWE. Warszawa.

Kukliński A., 2000. Metropolia Warszawy wobec wyznań procesów globalizacji. [w:] Globalizacja Polskich Metroplii. Pod red. A. Kukliński, J. Kołodziejski, T. Markowski, W. Dziemianowicz, Euroreg Warszawa.

Makieła Z., 2000. Infrastruktura transportu Polski Poludniowo Wschodniej na tle systemu transportu Europy Środkowej. [w:] Dzialalność czlowieka i jego środowisko, pod red. Z. Zioło. Wydawnictwo Naukowe Akademii Pedagogicznej w Krakowie. Kraków. 


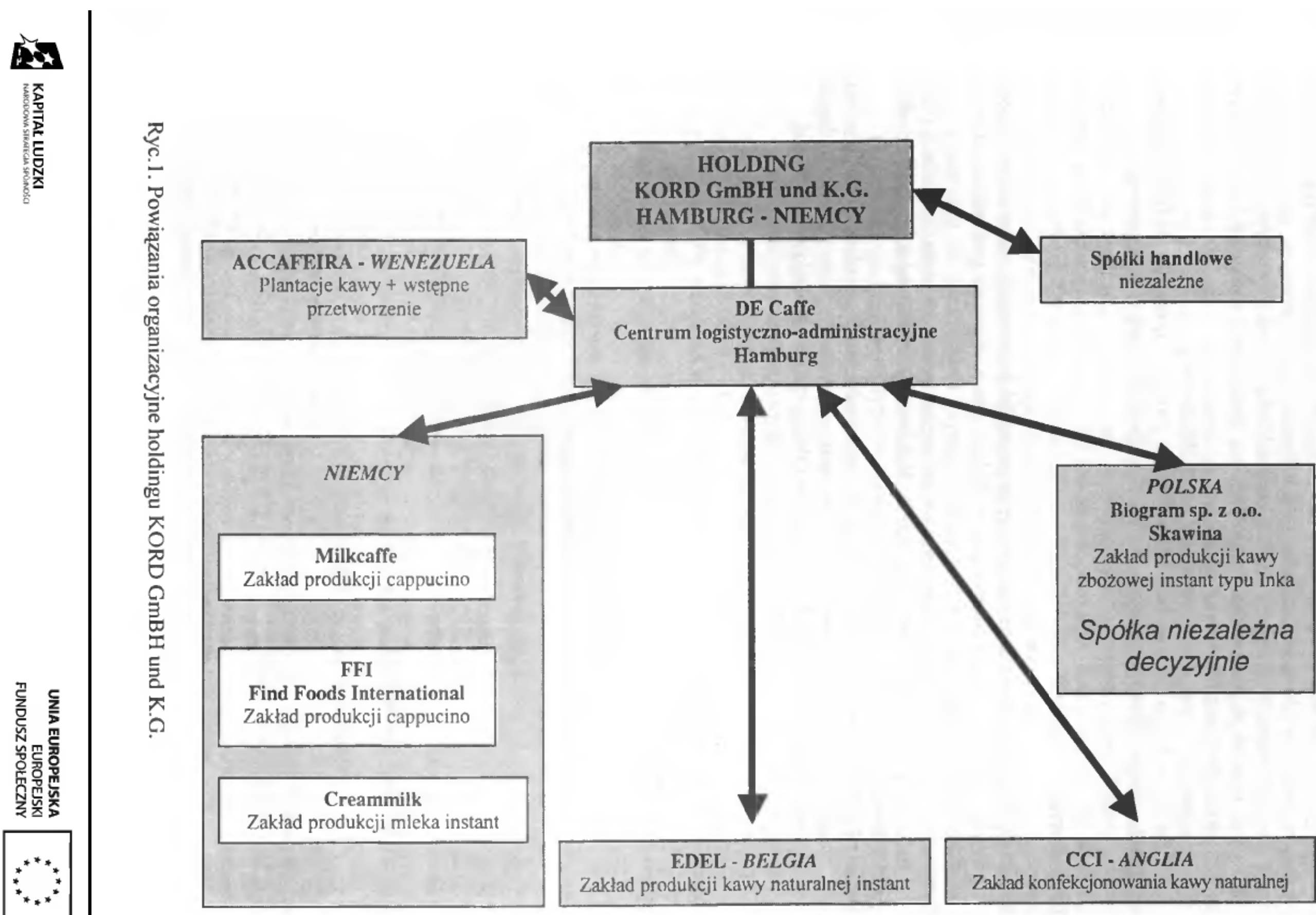

